\title{
Arousing Metacognitive Awareness in English Listening Comprehension
}

\author{
Shu Zhou \\ China West Normal University \\ No. 1 Shi da Road, Shun qing District, Sichuan Province, China
}

\begin{abstract}
This paper probes into L2 learners' metacognitive strategies use in listening comprehension in college English course, attempting to arouse metacognitive awareness so as to improve students' English listening proficiency.
\end{abstract}

Keywords: metacognitive strategies metacognitive awareness English listening comprehension

\section{BACKGROUND OF THE STUDY}

College English is a compulsory course for non-English majors in Chinese universities. However, the teaching and learning of it are far from satisfactory. There are large classes with limited time and resources. The levels of students vary in English, but comparatively most of them are poor in listening and speaking. Among the four skills of English, listening comes first and it becomes the bottleneck problem for English learners in college. A class survey indicates students spend $65 \%$ of time of English learning in memorizing words, only $9 \%$ left for listening and speaking. Most of their goals of leaning English are to pass exams. The survey also shows them have great trouble in listening comprehension. Failing to grasp the gist and certain details are common for them.

This paper probes into L2 learners' metacognitive strategies in L2 listening training in college English classroom, attempting to focus on the process of listening so as to improve students' listening proficiency.

\section{Metacognitive STRATEgIES IN L2 LiSTENING}

Metacognitive strategies are advanced executive skills which may involve planning for learning, monitoring the learning process, and evaluating the success of learning activities(1).

In this study, it is necessary to emphasis the essential role metacognitive strategies play in the framework of strategy use. Early in 1990, Vann Abraham found out from his study that unsuccessful learners do not lack of cognitive strategies or tactics. Instead, they fail to grasp when and under what circumstance to adopt suitable strategies or tactics(2). Research indicates the application of strategies, in particular metacognitive strategies, help to improve listening comprehension. O'Malley \& Chamot(1)pointed out metacognitive strategies has potential effect on promoting listening Compreh- ension, which arm learners with self-regulation and self-adjustment. Table 1 illustrates the metacognitive strategies used in listening comprehension by Vandergrift(3).

Table1. Metacognitive listening comprehension strategies

1. Planning: growing an awareness of how to accomplish a listening task, forming a proper action plan to overcome difficulties that you may well meet during the listening process.

Advance organization: clarifying the specific purpose of an anticipated listening task and/or bringing out strategies for dealing with it.

Directed attention: deciding before band to concentrate full attention on the listening task and to ignore unrelated distracters; holding your attention throughout the listening process.

Selective attention: choosing to focus on specific parts of language input or details assisting in comprehending and/or task completion.

Self-management: knowing about the conditions that aid one successful completion of listening tasks and managing those conditions. 
2. Monitoring: during the process of a listening task, supervising, controlling, checking, verifying, or correcting one's understanding or listening performance.

Comprehension monitoring: checking, verifying, or correcting one's comprehending at the local level.

Auditory monitoring: using one's 'ear' to distinguish the language (how something sounds) to comprehend.

Double-check monitoring: checking, verifying, or correcting one's comprehending of the task or during the second time through the oral text.

3. Evaluation: exam the fulfillment of one's listening comprehension on the accuracy and completeness of the understanding of the oral text.

Performance evaluation: judging one's performance of the task in general.

Strategy evaluation: judging one's strategy use.

4. Problem identification: clearly and exactly identifying the key point requiring for resolution in a task or finding out a detail of the task that hinders its smooth completion.

Adapted from Vandergrift (1997)

\section{RESEARCH METHODOLOGIES}

\subsection{Research Question}

The research is aimed to answer the question: is there any enhancement of metacognitive knowledge and strategy use (planning and evaluation, directed attention, person knowledge, mental translation, problem-solving) over time?

\subsection{Participants}

The study involved 56 sophomores of a class A who are majored in Chinese in China West Normal University. Students in class A are high-skilled English learners with the average score of 110, compared with class B with the lower average score of 90. Since Goh(4)and Vandergrift (5) have testified more skilled learners tend to be more metacognitively aware of the strategy use and the process of listening comprehension, the participants of this study are chosen from class A so that they can acquire the passage dictation training more effectively and their metacognitive awareness could be more easily promoted if the assumption of this study is reasonable.

\subsection{Instruments---Reflective Journals}

Reflective journals were collected for the data collection of qualitative research. Participants reflected on the process that was involved in arriving their dictation tasks in each step. They also required writing about their thoughts on the use of mtacognitive knowledge and strategies in each step of dictation and how it affects their listening process. The following are some guiding questions which students had to think about in their reflective journals:

1. What were your errors? (such as tense, spelling, singular or plural form, word missing, and so on)

2. How to avoid the mistakes?

3. What strategies facilitated your dictation, and what were ineffective in passage dictation?

4. What your feelings, attitudes, and thoughts when you were taking the passage dictation?

5. What changes might be made? What would you plan to do next time?

\subsection{Research Procedure}

The study involved a class of 56 sophomores. At the beginning stage, there were a pre-test of listening comprehension taken to test students' current performance on passage dictation. Then, the experimental treatment was given in the form of passage dictation with the application of metacognitve knowledge and strategy use twice a week at the beginning 20 minutes of the class. The 20 dictation passages were selected from the text book of college English listening comprehension book 1, book 2, and book 3. The passage should be interesting, or amusing, covering all types of literature and meeting their level and needs. The length of the passage ranged from 112 words to 155 words, which means some of the passage was extracted from a part of a longer passage. Besides, every time student$\mathrm{s}$ were required to write down reflective journals about the process of the passage dictation. The main objective of the experimental treatment was to explore the effect of passage dictation with metacognitve knowledge and strategy use on the enhancement of non-English majors' listening 
proficiency. Finally, students were to write reflective journals to check the change of their metacognitve awareness and strategy use.

\subsection{The Intervention----Passage Dictation Training}

The key feature of the intervention program involved the use of passage dictation through process-based steps with metacognitive knowledge and strategy use in it. The intervention took place in a period of 10 weeks with 20 times passage dictation training in total. A series of 20 passage dictations which were characterized by the same contents were carried out for both the control and experimental groups at the beginning of every class twice a week. The training took place at the beginning of each lesson because students can focus their attention on listening best at that time without the intervention of other activities in the class. The duration of each lesson was twenty minutes.

Table 2 shows the pedagogical steps of passage dictation training with the strategies in a metacognitive process.

Table2. Pedagogical steps of passage dictation and strategy use in metacognitive processes

\begin{tabular}{|c|c|c|c|}
\hline Stages of passage dictation & $\begin{array}{l}\text { Metacognitive } \\
\text { strategies }\end{array}$ & $\begin{array}{l}\text { Cognitive } \\
\text { strategies }\end{array}$ & $\begin{array}{l}\text { Social-affective } \\
\text { strategies }\end{array}$ \\
\hline $\begin{array}{l}\text { Stage1(planning/predicting) } \\
\text {-students get familiar with the title of the } \\
\text { listening material making predictions } \\
\text { about what it might be or entail } \\
\text {-students brainstorm for possible ideas or } \\
\text { words that emerge from the text }\end{array}$ & $\begin{array}{l}\text { Planning/directed } \\
\text { attention }\end{array}$ & $\begin{array}{l}\text { Inferencing } \\
\text { Resourcing } \\
\text { grouping }\end{array}$ & $\begin{array}{l}\text { Lowering anxiety } \\
\text { Self-encouragement } \\
\text { cooperation }\end{array}$ \\
\hline $\begin{array}{l}\text { Stage } 2\left(\text { the } \mathbf{1}^{\text {st }} \text {-time listening) }\right. \\
\text {-students listen to the passage without } \\
\text { taking down anything to get what the } \\
\text { text is talking about(general idea) }\end{array}$ & $\begin{array}{l}\text { Monitoring/selective } \\
\text { attention/ } \\
\text { Planning/problem } \\
\text { solving }\end{array}$ & $\begin{array}{l}\text { Top-down } \\
\text { process } \\
\text { inferencing }\end{array}$ & \\
\hline $\begin{array}{l}\text { Stage 3(the } 2^{\text {nd }} \text {-time listening) } \\
\text {-students listen to the text to get the } \\
\text { procedure of the passage with the } \\
\text { indication of transitional words and take } \\
\text { them down }\end{array}$ & $\begin{array}{l}\text { Selective attention } \\
\text { /monitoring/ } \\
\text { problem solving }\end{array}$ & $\begin{array}{l}\text { Top-down } \\
\text { process } \\
\text { Note-taking } \\
\text { Inferencing } \\
\text { Transfer }\end{array}$ & $\begin{array}{l}\text { Questioning for } \\
\text { clarification }\end{array}$ \\
\hline $\begin{array}{l}\text { Stage } 4 \text { (the } 3^{\text {rd }} \text {-time listening) } \\
\text {-students listen to the text to get the key } \\
\text { information of each points in the passage } \\
\text { and take down the key words in the } \\
\text { procedure of the passage. } \\
\text { - students retell the passage with these } \\
\text { key information and their own words }\end{array}$ & $\begin{array}{l}\text { Selective attention } \\
\text { /monitoring/ } \\
\text { problem solving }\end{array}$ & $\begin{array}{l}\text { Top-down } \\
\text { process } \\
\text { Note-taking } \\
\text { Elaboration } \\
\text { Summarization }\end{array}$ & \\
\hline $\begin{array}{l}\text { Stage } 5 \text { (the } 4^{\text {th }} \text {-time listening) } \\
\text { - students listen to the text with a pause } \\
\text { of } 8 \text { seconds after each sentence to take } \\
\text { down every sentence of the passage }\end{array}$ & $\begin{array}{l}\text { Monitoring/problem } \\
\text { solving/ } \\
\text { selective attention }\end{array}$ & $\begin{array}{l}\text { Bottom-up } \\
\text { process } \\
\text { Elaboration }\end{array}$ & \\
\hline $\begin{array}{l}\text { Stage6(reflection) } \\
\text { - student do the } 5^{\text {th }} \text {-time listening with the } \\
\text { script in the screen to check their } \\
\text { dictation work } \\
\text { - students evaluate the listening process } \\
\text { and find possible ways to improve the } \\
\text { next dictation } \\
\text { - write down reflective journals }\end{array}$ & Evaluation/planning & $\begin{array}{l}\text { Bottom-up } \\
\text { process }\end{array}$ & cooperation \\
\hline
\end{tabular}

(Based on the Metacognitive Cycle, Vandergrift, 2004)(6) 


\subsection{Results From Reflective Journals}

During ten weeks' passage dictation, each student handed in 10 journals. There were 56, and theoretically speaking, there would be 560 journals. But, because some students hadn't given in all their journals, and some journals were meaningless to the research, a total of 213 journals were available for analysis in this study. The names of the students that will mention are not the actual names but their pseudonyms. The data gathered from the reflective journals are samples of the actual writings by students without any change. The results are presented in terms of person, task and strategic knowledge which according to wenden(7)make up what are together known as metacognitive knowledge.

\subsubsection{Person Knowledge}

Person knowledge, which according to Wenden(7), is the knowledge that learners have about themselves with regard to the cognitive and affective factors that facilitate learning. This is reflected in the journals of experimental group. The following statements are some typical response to person knowledge in their journals:

1. I don't want to do listening, because it is difficult and time-consuming. My fear to English listening keep this problem unsolved. After dictation training, I found that it is not that hard as I used to think. The specific steps in our listening tasks help us get the main idea and more details. I believe if I carry on the training, my listening comprehension ability will be improved.

2. Why my listening is poor? Perhaps I do not do it carefully, or my attitude towards English learning is negative. In this way learning English becomes desperate for me. As for my future work, listening for half an hour every day is necessary with notes taken down carefully while listening.

3. English listening has been my long-term problem since middle school. I always try to catch every word's meaning while listening, but in vain. Often, my mind slips to somewhere else...I found that it is wrong to catch every word's meaning. If we focus on sentence which is the larger unit, we may do listening tasks much better.

Students displayed evidence of person knowledge and they wrote down what they considered to be obstacles and factors that affected their listening. They were able to express their thoughts about their preferences, styles and habits about listening which they were aware of. From the 3 examples we can see at the beginning all of them held negative attitude toward listening. They felt nervous and confused about it and refuse to take it seriously. Gradually, with the dictation training carrying on, they were aware of their problems in listening, like the problems of listening habits, attitudes, and the way of listening. They realized the importance to change them so as to improve.

\subsubsection{Task Knowledge}

Task knowledge which refers to what students know about the purpose, demands and nature of learning tasks is evident in the reflective journals of experimental group.

1. The listening material had something to do with what we had learned in college English book 3. Hence, it is much easier in listening. Therefore if you want to listen well, it is important to read extensively and learn more new words.

2. When doing listening exercise, I often feel confused and my mind is blank. This results in inefficient listening. During dictation training, I realized that if we could follow certain steps, like first get familiar with background information before listening, second listen for main idea, third listen for structure, last listen for details, listening comprehension would be much easier for us. Therefore, planning and proper methods are important.

3. Dictation exercise helps me understand I should listen with purpose. Prediction about the listening material improves the outcome of listening practice.

From the above-mentioned examples, we got to know that some of them came to be aware of finding out the purpose of listening to the text. They realized to get what they wanted with proper strategies in each steps in dictation work, which could also facilitate them in other types of listening exercise. In example 2, the student mentioned his detailed procedure on how to listen effectively, which was the exact reflection on his metacognitive awareness of task knowledge. The nature and demands of the 
listening task was clearly understood by students. What's more, they began to think about how to listen according to different tasks.

\subsubsection{Strategic knowledge}

Wenden(7) mentioned Strategic knowledge refers to the awareness one has with regard to the effective use of strategies, such as cognitive, metacognitive and socio-affective strategies, and how best to approach language learning. The use of Strategic knowledge especially the metacognitive strategies were reported by, and there were some differences for their dictation at the beginning time and the latter.

Table3. The reported metacognitive strategies in journals before and after dictation program

\begin{tabular}{|l|l|l|}
\hline Metacognitive & Before training & After training \\
\hline strategies & $\begin{array}{l}\text { 1.I'm afraid of listening all the time. } \\
\text { Listening practice makes me become } \\
\text { as stubborn as a machine. }\end{array}$ & $\begin{array}{l}\text { 1. Teacher leads us to understand and brainstorm } \\
\text { the related topic before listening to the materials. I } \\
\text { found this is much better than prepare nothing. } \\
\text { Sometimes you may find that it is similar or just } \\
\text { like what you imaged before. }\end{array}$ \\
\cline { 2 - 4 } & $\begin{array}{l}\text { 2.It is difficult to concentrate on the } \\
\text { listening materials. If I heard some } \\
\text { new words or if there is distraction, } \\
\text { my mind will probably slip away. }\end{array}$ & $\begin{array}{l}\text { 2. Like teacher instructed, we need to force } \\
\text { ourselves to focus our attention, selecting attention } \\
\text { to main idea, structure, and details in each steps. If } \\
\text { I stick to the way with concentration and purpose } \\
\text { in each step, I can do it much better. }\end{array}$ \\
\cline { 2 - 3 } & $\begin{array}{l}\text { 3. English listening always makes } \\
\text { me headache. There seems no way } \\
\text { for me to improve. What I know is to } \\
\text { work harder and listen more, but still } \\
\text { in vain. }\end{array}$ & $\begin{array}{l}\text { 3. It is necessary to reflect on your listening } \\
\text { practice every time, through which we can find } \\
\text { out the problem and figure out how to make } \\
\text { improvement. }\end{array}$ \\
\hline
\end{tabular}

According to Vandergrift's Metacognitive listening comprehension strategies (1997), the reported metacognitive strategies were classified into 4 parts, namely planning, monitoring, evaluating and problem-solving.

(i) Planning,

The student in example 1 mentioned through the guided dictation training he learned to make prediction on the content of the text before listening so as to better understand the meaning of the passage with directed attention. And it was proved that some of their guessing was similar to the listening materials. Some of the students also stated that they could selective their attention on specific aspects of the dictation task according to the listening demands. Example 2 stated that in stage 3 of the dictation training attention should be focused on the transitional words to assist in figuring out how many points it mentioned in the passage. In a word, they learned to plan for their listening task through dictation program.

(ii) Monitoring

Monitoringreferred to checking, verifying, or correcting one's comprehension or performance in the course of a listening task. In their journals it is emphasized with teacher's guidance they learned to adjust their listening strategies, and correct their comprehension in time during each stage of the dictation. Although only a few mentioned about the metacognitive strategies of monitoring, it was hard for them to become self-monitored in a short time.

(iii) Evaluating

Students' reflective journals were the best evidence for their self-evaluation. As student in example 3 mentioned in table 3, the reason why for a long time they hadn't found the way to improve listening was partly because they thought less about their listening performance. With the dictation program, they reflected both their exact problems and advantages in their journals, which helped them to perform better next time. 
(iv) Problem-Identification

Many mistakes in their dictation were identified in their writing, including spelling mistakes, grammatical mistakes, pronunciation errors, comprehending errors and so on. These self-identified problems effectively arouse their awareness of how to prevent them in the future.

Generally speaking through the analysis of their reflective journal, more positive attitude toward passage dictation training was received, which was contrary to their previous attitude towards listening exercises. The metacognitive awareness was aroused in dictation work through the reflection of metacognitive knowledge in their journal.

\section{IMPLICATIONS OF THE RESEARCH}

The passage dictation approach provided them the chance to be exposed to the process-based listening. Through their dictation work and diaries, it is evident that dictation training helps them be conscious of their strengths and weakness in listening. They've learnt how to use strategies to solve problems during the listening process. Raising students' metacognitive awareness in passage dictation training encourage them to participate in the process of planning, mentoring, and evaluating, which has ultimately fostered their learning motivation and enhanced the language proficiency.

Besides, through this study students can not only learn a new listening approach to improve their listening proficiency, they are also able to learn how to deal with different listening tasks with proper strategies. The enhancement of metacognitive awareness and strategy use help them become selfregulated on their learning, which could apply to all kinds of L2 learning.

Last, the study can also provide college English teachers a new mode of process-based listening instruction. At present the listening comprehension lesson of college English in China are mainly product-based, and they are given less attention. This study will serve to provide more knowledge especially in terms of process-approach in the teaching of listening comprehension.

\section{REFERENCES}

[1] O'Malley, M., \&Chamot, A.U. (1990) Language strategies in second language acquisition. Cambridge: Cambridge University Press.

[2] 吴增生 (1994), 值得重视的“学习者策略”的研究[J], 《现代外语》, 第四期。

[3] Vandergrift,L.(2003a). From prediction through reflection: Guiding students through the process of L2 listening. The Canadian Modern Language Review.59(3), 425-440

[4] Goh,C.(1997). Metacognitive awareness and second language listeners. English Language Teaching Journal, 51(4), 361-369.

[5] Vandergrift,L.(2003b). Orchestrating strategy use: Toward a model of the skilled second language listener .Language Learning.53(3), 463-496

[6] Vandergrift,L.(2004). Listen to learn or learn to listen. Annual Review of Applied Linguistics. 24, 3-25.

[7] Wenden, (1991).Learner strategies for learner autonomy. Hemel Hempstead: Prentice Hall.

\section{AUTHOR's BIOGRAPHY}

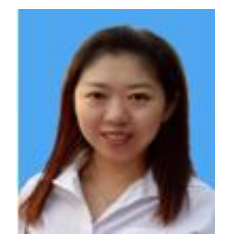

Shu Zhou, Lecturer, from The College of Foreign Language Education in China West Normal University, studying in English Language teaching and curriculum. 